\title{
PENGARUH METODE PENGOLAHAN TERHADAP KANDUNGAN TANIN DAN SIFAT FUNGSIONAL TEPUNG PROSO MILLET (Panicum miliaceum)
}

\section{The Effect of Processing Method on Tanin Content and Functional Properties Proso Millet (Panicum Miliaceum) Flour}

\author{
Putu Eka Ditya Mahendra' ${ }^{1}$, Ni Luh Ari Yusasrini' ${ }^{2)}$, Desak Putu Kartika Pratiwi ${ }^{2}$ \\ ${ }^{1}$ Mahasiswa Jurusan Ilmu dan Teknologi Pangan, Fakultas Teknologi Pertanian, Unud \\ ${ }^{2}$ Dosen Jurusan Imu dan Teknologi Pangan, Fakultas Teknologi Pertanian, Unud \\ Kampus Bukit Jimbaran, Badung-Bali
}

\begin{abstract}
The aim of this research were to determine the effect of processing methods on tannin content, functional properties proso millet (Panicum miliaceum) flour and determine which method can produce the lowest tannin content and the best functional properties. The Completely Randomized Design (CRD) was used in this research with 4 type of processing method treatments, such as: direct method, germination method, fermentation method, and germinationfermentation method. The treatment was repeated four times to obtain 16 experimental units. Data from the research results were analyzed by variance and if the treatment had a significant effect, then followed by Duncan's Multiple Range Test (DMRT). The results showed that the treatment of proso millet processing method had a highly significant effect $(\mathrm{P}<0.01)$ on yield, water content, ash content, tannin content, water absorption capacity, oil absorption capacity, swelling power, and solubility. The best treatment was produced by proso millet flour with germination-fermentation processing method was able to produce the lowest tannin content on $0.59 \%$ with a yield value $65.47 \%$, water content $12.36 \%$, ash content $1.45 \%$, water absorption capacity $172.85 \%$, oil absorption capacity of $107.73 \%$, swelling power of $10.11 \mathrm{~g} / \mathrm{g}$, and water solubility index of $44.10 \%$.

Keywords: proso millet, processing method, tannin content, functional properties, flour.
\end{abstract}

\section{PENDAHULUAN}

Millet (Panicum miliaceum) merupakan salah satu jenis serealia sumber utama penyedia energi, protein, vitamin, dan mineral. Kandungan gizi pada biji millet tidak kalah dengan serealia jenis lainnya seperti gandum, jagung, beras, dan lainnya (Hartono, 2010). Proso millet mengandung karbohidrat $84,40 \%$; protein $12,30 \%$; lemak $1,70 \%$; dan serat $0,90 \%$ (Widyaningsih dan Mutholib, 1999) serta kandungan air 8,67\% dan abu 3,25\% (National Nutrient Database, 2012). Pemanfaatan millet sebagai bahan pangan di Indonesia masih sangat rendah, ini dikarenakan kurangnya pengetahuan masyarakat mengenai potensi millet sebagai bahan pangan alternatif.

Peningkatan pemanfaatan biji millet dapat diupayakan dengan mengolah biji millet menjadi tepung. Keuntungan pengolahan biji millet menjadi tepung yaitu lebih mudah dan praktis diaplikasikan serta memiliki daya simpan yang lebih lama. Tepung merupakan salah satu bentuk alternatif produk setengah jadi yang dianjurkan karena lebih tahan disimpan, mudah dicampur, diperkaya zat gizi (difortifikasi), dan diolah menjadi produk pangan seperti roti, kue, mie dan lainnya (Sulistyaningrum et al., 2017). Sebelum diolah, kandungan zat antigizi pada millet merupakan kelemahan yang harus dihilangkan sebelum siap dijadikan tepung. Salah satu zat antigizi pada millet yaitu tanin.

Kandungan tanin yang terdapat pada biji millet cukup tinggi yakni mencapai 2,7\% - 10,2\% (Schons et al., 2012). Tanin merupakan senyawa yang termasuk dalam golongan polifenol yang 
dapat berikatan dengan protein membentuk senyawa kompleks sehingga mengurangi daya cerna protein dan apabila berikatan dengan enzim pada sistem pencernaan juga dapat mengurangi aktivitas enzim tersebut.

Tepung millet yang dihasilkan diharapkan memiliki sifat fungsional yang mirip dengan tepung yang ada di pasaran sehingga dapat dimanfaatkan sebagai bahan pembuatan cookies, snack bar, dan sejenisnya. Sifat fungsional merupakan sifat yang mempengaruhi komponen dari suatu bahan selama proses persiapan, pengolahan, penyimpanan dan konsumsi. Uji kapasitas penyerapan air, kapasitas penyerapan minyak, swelling power dan indeks kelarutan tepung dalam air dapat membantu menentukan sifat fungsional tepung sehingga memudahkan aplikasinya dalam pembuatan produk pangan seperti cookies, snackbar, ataupun brownies.

Perkecambahan pada kacang - kacangan maupun serealia dapat meningkatkan nilai gizi dan menurunkan senyawa antigizi seperti tripsin inhibitor, asam pitat, pentosane, dan tanin Aminah (2012). Hal ini sesuai dengan penelitian Onyago et al., (2013) bahwa perkecambahan dapat menurunkan zat antigizi pada sorghum merah, sorghum putih, dan pearl millet.

Perkecambahan dapat mempengaruhi sifat fungsional tepung diduga karena adanya proses perendaman yang mengakibatkan komponen larut air seperti natrium kalium, amilosa, tanin yang hilang selama perendaman sehingga mempengaruhi kadar abu, swelling power, dan kandungan tanin. Selain perendaman, perkecambahan juga mengakibatkan perombakan makromolekul seperti pati, lemak, protein oleh enzim yang ada selama proses katabolisme terjadi. Perombakan ini terjadi agar memudahkan perpindahan molekul tersebut pada titik tumbuh biji (Ikbal, 2015).

Kandungan tanin juga dapat dikurangi dengan cara fermentasi. Tanpa penambahan starter, mikroba dominan yang terdapat pada serealia yaitu bakteri asam laktat dan khamir mendukung terjadinya fermentasi spontan pada serealia (Paiki, 2013). Salah satu metode fermentasi yang dapat terjadi secara spontan adalah fermentasi sub merge. Setiarto (2016) menyatakan bahwa kandungan tanin pada tepung sorgum dapat turun $42,65 \%$ melalui fermentasi.

Proses fermentasi menyebabkan perubahan komponen yang ada pada biji millet. Perubahan ini terjadi karena metode fermentasi submerge yang menggunakan media cair menyebabkan hilangnya komponen larut air seperti tanin, kalium, amilosa, natrium. Selain itu air juga menyebabkan peningkatan aktivitas mikroba alami pada biji millet. Aktivitas mikroba pada saat fermentasi berlangsung menyebabkan perubahan komponen makromolekul seperti pati, lemak, protein yang dipecah oleh enzim hasil sekresi mikroba menjadi komponen yang lebih sederhana. Komponen - komponen ini diperlukan mikroba untuk kelangsungan hidupnya (Yulia, 2009). Kombinasi perkecambahan dan fermentasi diharapkan dapat menurunkan kandungan tanin lebih banyak dan menghasilkan sifat fungsional tepung proso millet terbaik.

Berdasarkan hal tersebut, perlu dilakukan penelitian pengaruh metode pengolahan tepung 
proso millet terhadap kandungan tanin dan sifat fungsionalnya. Dengan tujuan untuk mengetahui pengaruh metode pengolahan tepung proso millet dan menentukan metode mana yang menghasilkan tepung terbaik.

\section{METODE PENELITIAN}

\section{Tempat dan Waktu}

Penelitian dilaksanakan di Laboratorium Pengolahan Pangan, Laboratorium Mikrobiologi Pangan, Laboratorium Biokimia dan Nutrisi, dan Laboratorium Analisis Pangan Program Studi Ilmu dan Teknologi Pangan Fakultas Teknologi Pertanian Universitas Udayana. Penelitian dilaksanakan dari bulan September sampai bulan Desember 2018.

\section{Bahan dan Alat}

Bahan utama yang digunakan dalam penelitian ini adalah biji proso millet (Panicum miliaceum) yang diperoleh dari Pasar Satria di Jalan Veteran Denpasar. Bahan yang digunakan untuk analisis meliputi aquades, alkohol (Merck), $\mathrm{HCl}$ (Merck), Indikator pp, $\mathrm{NaOH}$ (Merck), larutan reagen Nelson A dan Nelson $\mathrm{B}, \mathrm{H}_{2} \mathrm{SO}_{4}$ (Merck), KI, larutan Na-thiosulfat, amilum, asam tanat (Sigma), reagen Folin-Denis (Merck), $\mathrm{Na}_{2} \mathrm{CO}_{3}$ (Merck), minyak goreng.

Alat yang digunakan pada penelitian ini adalah timbangan analitik (sartorius), oven (Labo DO225), spektrofotometer UV-VIS (Biochrom Libra), eksikator, cawan porselin, muffle (Daihan), kertas saring, waterbath (Thermology), tabung reaksi (pyrex), vortex, sentrifuge (Centurion K241R), tabung sentrifuse, spatula, gelas ukur (pyrex), labu ukur (pyrex), gelas beker (pyrex), stirrer, pipet volume (pyrex) dan
Erlenmeyer (pyrex), wadah plastik, pisau, blender (maspion), waskom, kompor listrik, ayakan 60 mesh (Retsch).

\section{Rancangan Percobaan}

Rancangan penelitian yang dipakai dalam penelitian ini adalah Rancangan Acak Lengkap (RAL) dengan perlakuan 4 metode pengolahan yang terdiri dari: M1 (Metode Langsung), M2 (Metode Perkecambahan), M3 (Metode Fermentasi), M4 (Metode PerkecambahanFermentasi). Masing - masing perlakuan diulang sebanyak 4 kali, sehingga didapat 16 unit percobaan. Data hasil penelitian dianalisis dengan sidik ragam (ANOVA) dan apabila perlakuan berpengaruh terhadap variabel maka dilanjutkan dengan uji Duncan's Multiple Range Test (DMRT) (Gomez dan Gomez, 1995).

\section{Pelaksanaan Penelitian}

1. Pembuatan Tepung Millet Metode Langsung.

Proses pembuatan tepung proso millet metode langsung dilakukan sesuai metode pada penelitian Dewi et al., (2018) yang telah dimodifikasi. Pembuatan tepung diawali dengan mencuci biji proso millet sebanyak $200 \mathrm{~g}$ dengan air agar kotoran maupun benda asing hilang. Selanjutnya dilakukan pengeringan menggunakan oven dengan suhu $60^{\circ} \mathrm{C}$ selama 2 jam. Biji yang telah kering digiling menggunakan blender dan diayak menggunakan ayakan 60 mesh.

\section{Pembuatan Tepung Millet Metode Perkecambahan.}

Biji proso millet sebanyak $200 \mathrm{~g}$ dicuci dengan air sampai bersih kemudian direndam dalam air selama 12 jam. Setelah direndam, 
ditiriskan dan proso millet diletakkan pada wadah yang ditutupi kain basah dan dikecambahkan selama 120 jam. Selama perkecambahan berlangsung, setiap 12 jam proso millet disiram dengan air sebanyak $50 \mathrm{ml}$ secara merata. Proso millet yang sudah berkecambah kemudian dikeringkan menggunakan oven pada suhu $60^{\circ} \mathrm{C}$ selama 2 jam. Kecambah proso millet yang sudah kering kemudian digiling menggunakan blender dan diayak menggunakan ayakan 60 mesh.

\section{Pembuatan Tepung Millet Metode Fermentasi.}

Biji proso millet sebanyak $200 \mathrm{~g}$ dicuci terlebih dahulu dengan air hingga kotoran dan benda asing hilang. Selanjutnya diletakkan pada wadah (toples kaca) steril dan direndam dengan aquadest steril dengan ratio 1:2 (w/v) dalam keadaan tertutup, sehingga fermentasi spontan berlangsung. Fermentasi spontan dilakukan selama 24 jam. Setelah 24 jam, biji proso millet ditiriskan dan dikeringkan menggunakan oven pada suhu $60^{\circ} \mathrm{C}$ selama 2 jam. Dilakukan pengecilan ukuran menggunakan blender dan diayak menggunakan ayakan 60 mesh

\section{Pembuatan Tepung Millet Metode Perkecambahan-Fermentasi.}

Pembuatan tepung proso millet metode perkecambahan-terfermentasi dilakukan dengan menggabungkan metode perkecambahan (Dewi et al., 2018) dilanjutkan dengan metode fermentasi (Kindiki et al., 2015). Diawali dengan biji proso sebanyak 200 g millet dicuci dengan air hingga bersih, kemudian direndam selama 12 jam. Setelah 12 jam, biji proso millet ditiriskan dan diletakkan pada wadah yang ditutupi kain basah dan dikecambahkan selama 120 jam. Selama proses perkecambahan berlangsung, biji proso millet disiram dengan air 50ml secara merata setiap 12 jam sekali. Biji proso millet yang telah berkecambah kemudian dicuci dan diletakkan pada wadah steril (toples kaca) dan direndam aquadest steril dengan ratio 1:2 (w/v) dalam keadaan tertutup. Fermentasi spontan dilakukan selama 24 jam, setelah itu ditiriskan dan dikeringkan menggunakan oven pada suhu $60^{\circ} \mathrm{C}$ selama 2 jam. Setelah kering, kecambah proso millet terfermentasi digiling menggunakan blender dan diayak menggunakan ayakan 60 mesh.

\section{HASIL DAN PEMBAHASAN}

Hasil analisis rendemen, kadar air, kadar abu dan kandungan tanin pada tepung proso millet dapat dilihat pada Tabel 1. Hasil analisis kapasitas penyerapan air (KPA), kapasitas penyerapan minyak (KPM), Swelling Power, dan Kelarutan tepung proso millet dapat dilihat pada Tabel 2.

Tabel 1. Nilai Rata - Rata Rendemen, Kadar Air, Kadar Abu dan Kandungan Tanin Pada Perlakuan Metode Pengolahan Millet.

\begin{tabular}{lllll}
\hline Perlakuan & Rendemen $(\%)$ & Kadar Air $(\%)$ & Kadar Abu $(\%)$ & Kandungan Tanin $(\%)$ \\
\hline M1 & $84,60 \pm 2,42 \mathrm{a}$ & $8,94 \pm 0,07 \mathrm{c}$ & $3,40 \pm 0,22 \mathrm{a}$ & $2,69 \pm 0,02 \mathrm{a}$ \\
M2 & $79,27 \pm 1,23 \mathrm{~b}$ & $9,02 \pm 0,25 \mathrm{c}$ & $2,83 \pm 0,18 \mathrm{~b}$ & $2,19 \pm 0,26 \mathrm{~b}$ \\
M3 & $72,95 \pm 2,93 \mathrm{c}$ & $11,12 \pm 0,48 \mathrm{~b}$ & $2,64 \pm 0,21 \mathrm{~b}$ & $1,51 \pm 0,31 \mathrm{c}$ \\
M4 & $65,47 \pm 3,67 \mathrm{~d}$ & $12,36 \pm 0,60 \mathrm{a}$ & $1,45 \pm 0,13 \mathrm{c}$ & $0,59 \pm 0,39 \mathrm{~d}$ \\
\hline
\end{tabular}

Keterangan: Nilai rata - rata yang diikuti oleh huruf yang berbeda pada kolom yang sama menunjukkan berbeda nyata $(\alpha=0,05)$. 


\section{Rendemen}

Hasil sidik ragam menunjukkan bahwa perlakuan metode pengolahan berpengaruh sangat nyata $(\mathrm{P}<0,01)$ terhadap rendemen tepung millet. Berdasarkan Tabel 1 rendemen tepung berkisar antara $65,47 \%-84,60 \%$. Rendemen tepung proso millet tertinggi didapat pada perlakuan M1 yaitu $84,60 \%$, sementara rendemen terendah terdapat pada perlakuan M4 yaitu $65,47 \%$. Metode pengolahan menyebabkan perbedaan rendemen tepung yang dihasilkan. Metode pengolahan dengan perlakuan M2, M3, dan M4 terdapat proses perendaman. Proses ini diduga terjadi hilangnya komponen - komponen larut air pada biji proso millet.

Perlakuan M1 dihasilkan rendemen tepung proso millet tertinggi diduga karena singkatnya proses pengolahan tepung, sehingga tidak banyak komponen yang hilang. Perlakuan M1 tidak dilakukan proses perendaman sehingga komponen larut air seperti kalium, natrium, tanin tetap ada pada biji proso millet, serta tidak adanya perkecambahan dan fermentasi yang dapat merombak komponen kompleks menjadi lebih sederhana.

Perlakuan M2 terjadi penurunan rendemen tepung yang dihasilkan, ini diduga karena adanya proses perendaman yang dilanjutkan dengan perkecambahan yang menyebabkan terjadinya perombakan senyawa makromolekul seperti pati, lemak, dan protein menjadi lebih sederhana selama perkecambahan berlangsung. Banyaknya komponen yang dipecah pada saat perkecambahan menyebabkan rendemen tepung proso millet menurun. Penelitian Lombu (2018) juga menunjukkan penurunan rendemen dari $41,40 \%$ pada tepung jagung menjadi $40,36 \%$ pada tepung kecambah jagung.

Perlakuan M3 juga menunjukkan adanya penurunan rendemen tepung yang dihasilkan, ini diduga karena metode fermentasi submerge yang menggunakan media cair menyebabkan hilangnya komponen larut air pada proso millet. Selain itu terjadi perombakan makromolekul seperti amilum, lemak, dan protein menjadi substrat yang lebih sederhana akibat enzim yang disekresi oleh mikroba mengakibatkan rendemen tepung menurun. Penelitian Iswari et al., (2014) dibuktikan bahwa lama fermentasi menurunkan rendemen MOCAF, tepung MOCAF dengan lama fermentasi 0 jam menghasilkan rendemen $45,46 \%$ sedangkan pada lama fermentasi 72 jam menghasilkan rendemen sebesar 40,76\%.

Perlakuan M4 terjadi penurunan rendemen tepung yang lebih banyak dibandingkan perlakuan lainnya, ini dikarenakan kombinasi perkecambahan dan fermentasi dalam proses pengolahan tepung. Perkecambahan dan fermentasi sama-sama memecah makromolekul kompleks seperti amilum, lemak, protein, serat menjadi lebih sederhana sehingga rendemen tepung lebih banyak berkurang.

\section{Kadar Air}

Hasil sidik ragam menunjukkan bahwa metode pengolahan berpengaruh sangat nyata $(\mathrm{P}<0,01)$ terhadap kadar air tepung proso millet. Tabel 1 menunjukkan nilai rerata kadar air tertinggi dihasilkan pada perlakuan M4 yaitu $12,36 \%$, sedangkan rata - rata kadar air terendah dihasilkan pada perlakuan M1 yaitu 8,94\% dan 
tidak berbeda nyata dengan perlakuan M2 yaitu $9,02 \%$

Perlakuan M1 didapat tepung proso millet dengan kadar air terendah. Hasil kadar air terendah didapat diduga karena proso millet tidak mengalami kontak dengan air yang lama serta tidak terjadi perombakan senyawa kompleks menjadi senyawa sederhana, sehingga difusi air ke dalam biji proso millet lebih sulit terjadi. Berdasarkan hal tersebut dapat dinyatakan bahwa kadar air pada perlakuan M1 merupakan kadar air alami pada tepung proso millet. Menurut Prabowo (2010) kadar air tepung millet kuning sebesar $9,19 \%$.

Perlakuan M2 didapat hasil yang berbeda tidak nyata dengan perlakuan $\mathrm{M}$ 1, namun terjadi peningkatan kadar air dari 8,94\% pada perlakuan M1 menjadi 9,02\%. Peningkatan ini dikarenakan terjadi perkecambahan pada proses pengolahannya. Amilum, lemak, protein yang dirombak menjadi molekul yang lebih sederhana memudahkan difusi air ke dalam proso millet. Hasil penelitian Wisaniyasa dan Suter (2015) menunjukkan bahwa perkecambahan selama 2 hari tidak mengubah kadar air pada tepung kecambah kacang merah.

Perlakuan M3 digunakan metode submerge fermentation menyebabkan peningkatan kadar air dibanding perlakuan M1. Hal ini diduga karena karena proses difusi air ke dalam jaringan sel - sel biji proso millet, selain itu aktivitas mikroba yang merombak makromolekul seperti pati, lemak, protein menjadi senyawa yang lebih sederhana memudahkan air untuk berdifusi ke dalam sel proso millet. Pada penelitian Julianti et al., (2017) juga menunjukkan peningkatan kadar air pada proses fermentasi tepung ubi jalar ungu. Tepung ubi jalar ungu yang difermentasi dengan lama waktu 48 jam menunjukkan kadar air tertinggi yaitu $9,93 \%$ dibanding tepung yang difermentasi selama 24 jam yaitu $8,73 \%$.

Perlakuan M4 menghasilkan kadar air tertinggi dikarenakan pada metode ini proso millet mengalami kontak dengan air yang lebih lama dibandingkan perlakuan lainnya. Proso millet perlakuan M4 mengalami proses perendaman yang sama dengan perlakuan M2 yaitu selama 12 jam, selanjutnya setelah berkecambah dilakukan fermentasi submerge selama 24 jam. Proses tersebut diduga memungkinkan difusi air ke dalam sel - sel proso millet lebih banyak dan terbentuknya komponen proso millet yang lebih sederhana akibat proses perkecambahan yang memudahkan air untuk berdifusi ke dalam proso millet.

\section{Kadar Abu}

Hasil sidik ragam menunjukkan bahwa metode pengolahan berpengaruh sangat nyata $(\mathrm{P}<0,01)$ terhadap kadar abu tepung proso millet. Tabel 1 menunjukkan nilai rerata kadar abu tepung tertinggi dimiliki oleh perlakuan M1 yaitu sebesar 3,4\% sedangkan rata - rata kadar abu tepung terendah dimiliki oleh perlakuan M4 yaitu $1,45 \%$.

Perlakuan M1 menghasilkan tepung proso millet dengan kadar abu tertinggi. Hal ini diduga karena tidak dilakukannya proses perendaman yang mengakibatkan mineral larut air tetap ada hingga proses pengujian kadar abu. Singkatnya proses pengolahan tidak banyak mengubah 
komponen yang terdapat pada biji proso millet, sehingga dapat dikatakan kadar abu pada perlakuan M1 merupakan kadar abu alami pada tepung proso millet. Menurut Prabowo (2010) kadar abu tepung millet kuning sebesar 1,80\%.

Perendaman yang dilakukan pada perlakuan M2 sebelum perkecambahan diduga mempengaruhi kadar abu tepung yang dihasilkan, hal ini disebabkan oleh mineral yang larut dalam air seperti kalium dan natrium. Proses perendaman mengakibatkan larutnya kalium dan natrium sehingga mineral tersebut terbuang (Julianti et al., 2017). Hilangnya mineral larut air menyebabkan terjadi penurunan kadar abu tepung proso millet.

Fermentasi submerge yang digunakan pada perlakuan M3 juga mempengaruhi kadar abu tepung proso millet. Hilangnya mineral larut air seperti kalium dan natrium karena metode fermentasi submerge menyebabkan kadar abu pada tepung proso millet perlakuan M3 menurun. Julianti et al., (2017) menunjukkan bahwa kadar abu tepung ubi jalar oranye lebih tinggi dibandingkan tepung ubi jalar oranye hasil fermentasi. Pada tepung ubi jalar oranye didapat kadar abu sebesar 1,99\%, sedangkan fermentasi BAL selama 72 jam menghasilkan tepung ubi jalar oranye dengan kadar abu sebesar 1,31\%.

Perlakuan M4 didapat kadar abu tepung proso millet terendah. Hal ini diduga akibat kontak yang lebih lama dengan air dibandingkan perlakuan lainnya, yaitu sebelum perkecambahan dan selama fermentasi berlangsung. Pada saat sebelum perkecambahan, biji proso millet perlakuan M4 direndam dengan air selama 12 jam, lalu dikecambahkan, dan dilanjutkan dengan fermentasi yang menggunakan media cair selama 24 jam.

\section{Kandungan Tanin}

Hasil sidik ragam menunjukkan metode pengolahan berpengaruh sangat nyata $(\mathrm{P}<0,01)$ terhadap kandungan tanin tepung proso millet. Pada Tabel 1 dapat dilihat bahwa terjadi penurunan kandungan tanin akibat metode pengolahan terhadap kandungan tanin tepung proso millet. Nilai rerata kandungan tanin tertinggi diperoleh pada perlakuan M1 yakni sebesar 2,69\% sementara kandungan tanin terendah diperoleh pada perlakuan M4 yaitu sebesar $0,59 \%$. Penurunan kandungan tanin dari perlakuan M1 ke M2, M3, dan M4 ini diduga karena adanya proses perendaman, perkecambahan dan fermentasi.

Perlakuan M1 menghasilkan kandungan tanin tepung proso millet sebesar $2,69 \%$. Metode langsung yang dilakukan pada perlakuan M1 menunjukkan kandungan tanin alami yang terdapat pada biji proso millet. Hal ini sesuai dengan pernyataan Schons et al., (2012) yang menyatakan kandungan tanin yang terdapat pada biji proso millet cukup tinggi yakni mencapai $2,7 \%-10,2 \%$.

Perlakuan M2 terdapat perkecambahan yang menurunkan kandungan tanin pada proso millet. Penurunan kandungan tanin terjadi pada saat proses perendaman dimulai, dimana tanin merupakan senyawa yang mudah larut dalam air sehingga menyebabkan kandungan tanin pada proso millet berkurang. Setelah itu perkecambahan yang akan merombak senyawa 
karbohidrat menjadi gula sederhana oleh enzim amilase. Tanin yang struktur molekul di tengahnya terdapat gugus karbohidrat ikut dipecah sehingga tanin ikut larut. Hal ini dibuktikan pada Dewi et al., (2018) yang menyatakan bahwa proses perkecambahan dapat menurunkan kandungan tanin dari flakes millet yang dihasilkan. Kandungan tanin pada millet 0,61\% turun menjadi $0,31 \%$ pada flakes yang menggunakan tepung millet yang dikecambahkan selama 120 jam. Aminah (2012) menyatakan bahwa proses perkecambahan baik pada kacang kacangan ataupun serealia dapat meningkatkan nilai gizi dan menurunkan senyawa antigizi seperti tripsin inhibitor, asam fitat dan tanin. Pernyataan ini juga dibuktikan pada penelitian Megat (2012) yang menunjukkan hasil penurunan kandungan tanin akibat proses perkecambahan pada kacang kedelai, dari 5,67\% menjadi 4,07\%.

Proses fermentasi juga berpengaruh pada turunnya kandungan tanin pada biji proso millet. Perlakuan M3 terdapat proses fermentasi yang mengakibatkan turunnya kandungan tanin pada tepung proso millet. Hal ini dikarenakan pada proses fermentasi terdapat bakteri asam laktat (BAL) yang dapat menghidrolisis gula dan karbohidrat. Terhidrolisisnya karbohidrat juga menyebabkan tanin terhidrolisis dikarenakan gugus karbohidrat yang terdapat pada struktur molekul tanin. Tanin juga merupakan senyawa yang mudah larut dalam air, sehingga pada saat perendaman telah mengurangi kandungan tanin pada biji proso millet. Fermentasi terbukti mampu menurunkan kandungan tanin, yang mana telah dibuktikan pada penelitian Setiarto (2016) yang mampu menurunkan kandungan tanin hingga $33,69 \%$ pada tepung sorgum fermentasi.

Perlakuan M4 yang merupakan kombinasi antara perkecambahan-fermentasi menghasilkan tepung proso millet dengan kandungan tanin paling rendah. Jika dibandingkan dengan metode langsung, metode perkecambahan menyebabkan kandungan tanin turun menjadi 2,19\%, proses fermentasi menurunkan kandungan tanin menjadi 1,51\%, sedangkan perlakuan kombinasi (perkecambahan-fermentasi) menurunkan kandungan tanin yang menjadi 0,59\%.

Tabel 2. Nilai Rata - Rata KPA, KPM, Swelling Power, dan Kelarutan Tepung Pada Perlakuan Metode Pengolahan Millet.

\begin{tabular}{lllll}
\hline Perlakuan & KPA $(\%)$ & KPM $(\%)$ & Swelling Power $\mathrm{g} / \mathrm{g}$ & Kelarutan $(\%)$ \\
\hline M1 & $132,57 \pm 3,59 \mathrm{~d}$ & $85,69 \pm 1,18 \mathrm{~d}$ & $13,19 \pm 0,40 \mathrm{~b}$ & $25,69 \pm 0,38 \mathrm{c}$ \\
M2 & $147,68 \pm 3,42 \mathrm{c}$ & $89,07 \pm 1,20 \mathrm{c}$ & $8,81 \pm 0,51 \mathrm{~d}$ & $32,64 \pm 1,73 \mathrm{~b}$ \\
M3 & $165,79 \pm 3,41 \mathrm{~b}$ & $93,85 \pm 1,31 \mathrm{~b}$ & $14,20 \pm 0,29 \mathrm{a}$ & $26,78 \pm 0,20 \mathrm{c}$ \\
M4 & $172,85 \pm 3,62 \mathrm{a}$ & $107,73 \pm 1,79 \mathrm{a}$ & $10,11 \pm 0,24 \mathrm{c}$ & $44,10 \pm 1,56 \mathrm{a}$ \\
\hline
\end{tabular}

Keterangan : Nilai rata - rata yang diikuti oleh huruf yang berbeda pada kolom yang sama menunjukkan berbeda nyata $(\alpha=0,05)$.

\section{Kapasitas Penyerapan Air (KPA)}

Hasil sidik ragam menunjukkan metode pengolahan berpengaruh sangat nyata $(\mathrm{P}<0,01)$ terhadap KPA tepung proso millet. KPA merupakan variabel yang digunakan untuk mengukur besarnya kemampuan tepung untuk menyerap air, ini mempengaruhi kemudahan dalam menghomogenkan adonan tepung ketika 
dicampurkan dengan air. Tabel 2 dapat dilihat bahwa nilai KPA tertinggi dihasilkan oleh perlakuan M4 yaitu sebesar 172,85\%, sementara terendah dihasilkan pada perlakuan M1 yaitu sebesar 132,57\%. Terjadi peningkatan KPA secara berturut - turut dari perlakuan M1 ke M2, M3, dan M4.

Perlakuan M1 menunjukkan hasil KPA yang terendah, hal ini diduga karena proso millet tidak melalui proses pengolahan. Kompleksnya senyawa yang terkandung pada tepung proso millet M1 menyebabkan air sulit untuk diserap. KPA sangat dipengaruhi oleh molekul yang terdapat pada tepung. Hal ini dibuktikan pada penelitian Anita (2009) dan Aini (2016).

Perkecambahan pada perlakuan M2 meningkatkan kemampuan mengikat air pada tepung proso millet. Peningkatan KPA diduga disebabkan oleh pecahnya makromolekul seperti protein menjadi lebih sederhana dan agak renggang sehingga memudahkan untuk menyerap air. Protein yang merupakan senyawa hidrofilik berpengaruh terhadap KPA tepung. Pada penelitian Anita (2009) indeks penyerapan air pada tepung komak dan tepung kecambah kacang komak mengalami peningkatan dari 3,55 g/g menjadi $3,93 \mathrm{~g} / \mathrm{g}$.

Fermentasi pada perlakuan M3 juga diduga menyebabkan peningkatan KPA tepung. Menurut Aini (2016) proses fermentasi cenderung menyebabkan peningkatan KPA tepung jagung termodifikasi. Hal ini terjadi karena pecahnya makromolekul seperti pati, lemak, dan protein yang ada pada biji jagung menjadi molekul yang lebih sederhana. Makromolekul yang tadinya relatif kompak menjadi agak berporous karena terpecah menjadi molekul sederhana yang memiliki bobot massa kecil sehingga agak renggang dan lebih mudah menyerap air. Penelitian Aini (2016) menunjukkan bahwa tepung jagung termodifikasi memiliki kapasitas penyerapan air berkisar 117,8-146,1\% dengan hasil tertinggi diperoleh pada fermentasi selama 80 jam, sedangkan hasil terendah diperoleh pada waktu fermentasi 20 jam.

Perlakuan M4 yang merupakan kombinasi perkecambahan-fermentasi menghasilkan nilai KPA tertinggi dibanding metode lainnya. Hal ini diduga karena lebih banyak makromolekul seperti pati, lemak, dan protein pada biji proso millet yang dipecah. Makromolekul yang tadinya relatif kompak menjadi agak berporous karena terpecah menjadi molekul sederhana berbobot massa kecil sehingga agak renggang dan lebih mudah menyerap air.

\section{Kapasitas Penyerapan Minyak (KPM)}

Hasil sidik ragam menunjukkan bahwa metode pengolahan berpengaruh yang sangat nyata $(\mathrm{P}<0,01)$ terhadap KPM tepung proso millet. KPM merupakan variabel yang diukur berdasarkan jumlah minyak yang dapat diserap oleh sejumlah tepung. Tabel 2 terjadi peningkatan KPM dari perlakuan M1 ke M2, M3 dan M4. Nilai rata - rata KPM tertinggi dihasilkan oleh tepung M4 yaitu sebesar 107,73\%, sementara untuk rata - rata KPM terendah dihasilkan oleh tepung M1 yaitu $85,69 \%$.

Perlakuan M1 menghasilkan tepung proso millet dengan KPM terendah yaitu sebesar $85,69 \%$. Rendahnya KPM pada perlakuan M1 
diduga karena proses pengolahan yang singkat mengakibatkan masih banyaknya senyawa kompleks yang terkandung di dalam tepung M1 sehingga minyak lebih sulit diserap oleh tepung.

Perkecambahan pada perlakuan M2 menyebabkan meningkatnya KPM tepung. Peningkatan KPM disebabkan oleh penurunan kadar lemak akibat perombakan pada saat perkecambahan (Wisaniyasa et al., 2015). Saat biji akan berkecambah, terdapat enzim lipase yang dapat memecah lemak menjadi senyawa lebih sederhana dan memudahkan translokasi pada daerah - daerah tumbuh biji. Penelitian Wisaniyasa et al., (2015) dibuktikan bahwa semakin lama perkecambahan semakin tinggi juga kapasitas penyerapan minyaknya. Tepung kacang gude tanpa perkecambahan menghasilkan kapasitas penyerapan minyak sebesar 173,96\%, sedangkan tepung kacang gude dengan lama perkecambahan 72 jam menghasilkan kapasitas penyerapan minyak tertinggi yaitu $199,72 \%$.

\section{Meningkatnya KPM tepung perlakuan M3} diduga karena kadar lemak yang semakin menurun. Penurunan kadar lemak terjadi akibat adanya enzim lipase yang disekresi oleh bakteri asam laktat. Enzim lipase memecah lemak menjadi senyawa yang lebih sederhana seperti asam lemak dan gliserol. Aini (2016) yang menyatakan bahwa waktu fermentasi berpengaruh nyata pada kapasitas penyerapan tepung. Penelitian Aini (2016) juga dibuktikan bahwa KPM meningkat akibat fermentasi pada tepung jagung. KPM tertinggi diperoleh pada tepung jagung dengan lama fermentasi 80 jam sebesar $146,1 \%$. Semakin banyak senyawa kompleks yang pecah menjadi senyawa yang lebih sederhana, semakin mudah tepung untuk menyerap minyak (Aini, 2016).

Kombinasi perkecambahan dilanjutkan fermentasi perlakuan M4 menyebabkan lebih banyak senyawa kompleks yang dipecah sehingga mudah minyak diserap oleh tepung millet (Aini, 2016). Makromolekul seperti lemak mengalami degradasi pada saat perkecambahan yang disebabkan oleh enzim lipase yang disintesis oleh aleuron biji proso millet. Selanjutnya, pemecahan lemak terjadi lagi pada saat fermentasi dibantu oleh enzim lipase yang disekresi oleh mikroba.

\section{Swelling Power}

Hasil sidik ragam menunjukkan bahwa metode pengolahan berpengaruh sangat nyata $(\mathrm{P}<0,01)$ terhadap swelling power tepung proso millet. Swelling power merupakan kemampuan pati untuk mengembang jika dipanaskan pada suhu dan waktu tertentu. Pada Tabel 2 dapat dilihat bahwa nilai rata - rata swelling power terendah didapat pada perlakuan M2 yaitu sebesar $8,81 \mathrm{~g} / \mathrm{g}$, dan nilai rata - rata tertinggi didapat pada perlakuan M3 yaitu sebesar 14,2g/g. Terjadi penurunan swelling power pada perlakuan yang terdapat perkecambahan.

Nilai swelling power perlakuan M1 merupakan kemampuan mengembang alami dari pati proso millet. Metode langsung yang digunakan pada perlakuan ini tidak banyak menyebabkan perubahan struktur molekul dari biji proso millet akibat proses pengolahan. Perkecambahan dan fermentasi diduga dapat mempengaruhi nilai swelling power dari tepung proso millet. 
Berdasarkan Tabel 2 tepung proso millet dengan perlakuan M2 menghasilkan swelling power terendah, hal ini diduga karena proses perkecambahan menyebabkan perombakan makromolekul seperti pati menjadi gula - gula sederhana. Saat perkecambahan berlangsung terdapat enzim amilase disintesis pada aleuron akan merombak pati (baik amilosa maupun amilopektin) pada biji proso millet, sehingga terjadi penurunan amilosa dan amilopektin. Penurunan amilopektin menyebabkan swelling power juga menurun. Hal tersebut sesuai dengan pernyataan Adedeji (2014) menyatakan bahwa penurunan swelling power akibat perkecambahan terjadi akibat perombakan pati oleh enzim amilase menjadi glukosa. Menurut Wisaniyasa et al., (2015) perkecambahan menurunkan kemampuan swelling power kacang gude dari 5,3\% pada tepung kacang gude, menjadi 4,23\% pada tepung kecambah kacang gude.

Perlakuan M3 meningkatan swelling power diduga karena penurunan amilosa akibat fermentasi. Peningkatan swelling power disebabkan adanya substitusi gugus asetil yang menggantikan gugus hidroksil sehingga ikatan hidrogen menjadi lemah dan kurang rapat sehingga memudahkan air untuk masuk pada granula pati. Gugus asetil dihasilkan oleh bakteri asam laktat yang terdapat selama proses fermentasi proso millet. Saputro et al., (2012) menyatakan bahwa amilosa dianggap paling berperan dalam proses awal asetil. Semakin banyak gugus hidroksil yang tersubstitusi oleh gugus asetil maka kandungan amilosa di dalam pati akan menurun. Berkurangnya amilosa menyebabkan kadar amilopektin meningkat, dan juga sejalan dengan peningkatan swelling power. Amilopektin merupakan komponen yang berada daerah amorf yang renggang dan kurang padat pada pati sehingga mudah dimasuki air (Haryanti et al., 2014). Peningkatan swelling power juga ditunjukkan pada penelitian Julianti et al., (2017) yaitu tepung ubi jalar oranye pada fermentasi 24 jam menghasilkan swelling power $8,22 \mathrm{~g} / \mathrm{g}$ sementara tepung ubi jalar oranye yang dihasilkan pada fermentasi 72 jam menghasilkan nilai swelling power $8,62 \mathrm{~g} / \mathrm{g}$.

Perlakuan M4 yang merupakan kombinasi perkecambahan dilanjutkan fermentasi terjadi penurunan swelling power dikarenakan adanya perkecambahan di dalam proses pengolahannya. Penurunan yang terjadi tidak sama dengan perlakuan M2 akibat adanya proses fermentasi setelah perkecambahan. Pada perlakuan M4, proses fermentasi yang terjadi setelah perkecambahan diduga dapat meningkatkan swelling power akibat hilangnya amilosa selama fermentasi berlangsung.

\section{Indeks Kelarutan dalam Air (IKA)}

Hasil sidik ragam menunjukkan bahwa metode pengolahan berpengaruh sangat nyata $(\mathrm{P}<0,01)$ terhadap indeks kelarutan tepung proso millet dalam air. IKA merupakan jumlah tepung yang dapat larut dalam air. Pada Tabel 2 dapat dilihat nilai rata - rata IKA terendah didapat pada perlakuan M1 yaitu sebesar 25,69\% sementara tertinggi didapat pada perlakuan M4 sebesar 44,1\%. Terjadi peningkatan nilai IKA pada semua metode pengolahan proso millet, walaupun pada 
perlakuan M3 nilai yang dihasilkan tidak berbeda nyata.

Perlakuan M1 menghasilkan IKA tepung proso millet terendah, hal ini diduga karena singkatnya metode pengolahan yang digunakan. Metode langsung yang digunakan pada perlakuan ini tidak banyak mengubah struktur molekul dari biji proso millet, sehingga masih banyak terdapat makromolekul kompleks seperti pati, lemak dan beberapa protein tidak larut air pada perlakuan M1. Kelarutan juga dipengaruhi oleh ukuran partikel/ senyawa. Wisaniyasa et al., (2015) menyatakan bahwa pada umumnya semakin sederhana senyawa semakin mudah larut dalam air sehingga indeks kelarutannya semakin tinggi.

Perlakuan M2 mengakibatkan terjadinya peningkatan indeks kelarutan tepung dalam air. Hal ini terjadi karena adanya proses perkecambahan pada perlakuan ini. Perkecambahan merombak makromolekul seperti pati, lemak, dan protein menjadi senyawa lebih sederhana dengan bantuan enzim seperti amilase, lipase, dan protease yang diduga meningkatkan indeks kelarutan dalam air. Semakin sederhana komponen pada biji proso millet maka indeks kelarutan dalam air akan semakin tinggi. Hal ini dibuktikan pada penelitian Wisaniyasa et al., (2015) yang menunjukkan bahwa proses perkecambahan kacang gude meningkatkan kelarutan tepung dalam air. Kelarutan terendah didapat pada tepung kecambah kacang gude dengan lama perkecambahan 24 jam yaitu sebesar $13,73 \%$ sedangkan kelarutan tertinggi didapat dari tepung kecambah kacang gude dengan lama perkecambahan 72 jam yaitu sebesar $19,05 \%$.
Perlakuan M3 terdapat proses fermentasi yang eningkatnya nilai kelarutan. Hal ini diduga terjadi karena aktivitas bakteri yang terdapat pada proses fermentasi. Perombakan yang terjadi pada komponen yang susah larut dalam air seperti pati, lemak, dan protein akibat enzim amilase, lipase dan protease yang dilepas oleh mikroba menyebabkan peningkatan indeks kelarutan tepung yang dihasilkan. Pada penelitian Rahma (2017) disebutkan bahwa fermentasi selama 24 jam meningkatkan nilai kelarutan dari 0,094\% menjadi $0,126 \%$ dikarenakan degradasi tepung oleh bakteri menjadi gula sederhana.

IKA tertinggi didapat oleh perlakuan M4. Perlakuan ini terdapat perkecambahan yang merombak pati, lemak, dan protein menjadi lebih sederhana. Kemudian dilanjutkan fermentasi yang juga memecah makromolekul tersebut dengan bantuan enzim yang disekresi oleh bakteri sehingga semakin sederhana senyawa yang terdapat pada tepung perlakuan M4.

\section{KESIMPULAN DAN SARAN}

\section{Kesimpulan}

Berdasarkan hasil penelitian yang telah dilakukan, maka dapat disimpulkan beberapa hal sebagai berikut :

1. Metode pengolahan berpengaruh terhadap rendemen, kadar air, kadar abu, kandungan tanin, kapasitas penyerapan air, kapasitas penyerapan minyak, swelling power, dan indeks kelarutan tepung proso millet dalam air.

2. Tepung proso millet yang dihasilkan dengan metode pengolahan perkecambahan-fermentasi menghasilkan 
kandungan tanin terendah yaitu $0,59 \%$ dengan nilai rendemen sebesar 65,47\%, kadar air sebesar 12,36\%, kadar abu sebesar $1,45 \%$, kapasitas penyerapan air sebesar $172,85 \%$, kapasitas penyerapan minyak sebesar 107,73\%, swelling power sebesar $10,11 \mathrm{~g} / \mathrm{g}$, dan indeks kelarutan dalam air sebesar $44,10 \%$.

Adedeji, O.E. 2014. Effect of Germination Time on The Functional Properties of Maize Flour and The Degree of Gelatinization of Its Cookies. Academic Journals 8(1) : 4247. Nigeria.

Aini, N., G. Wijonarko, dan B. Sustriawan. 2016. Sifat Fisik, Kimia, Dan Fungsional Tepung Jagung Yang Diproses Melalui Fermentasi. AGRITECH. 36(2) :160-169.

Aminah, S dan H. Wikanastri. 2012. Karakteristik Kimia Tepung Kecambah Serealia dan Kacang - Kacangan dengan Variasi Blanching. Jurnal Surya Masyarakat. 978602-18809-0-6 : 209-217.

Anita, S. 2009. Studi Sifat Fisiko-Kimia, Sifat Fungsional Karbohidrat, dan Aktivitas Antioksidan Tepung Kecambah Kacang Komak (Lablab purpureus L. sweet). Skripsi. Institut Pertanian Bogor.

Dewi, IG. A. A. S. P. 2018. Pengaruh Lama Perkecambahan Millet (Panicum miliaceum) Terhadap Karakteristik Flakes. Skripsi. Universitas Udayana.

Haryanti, P., R. Setyawati dan R. Wicaksono. 2014. Pengaruh Suhu dan Lama Pemanasan Suspensi Pati serta Konsentrasi Butanol terhadap Karakteristik Fisikimia Pati Tinggi Amilosa dari Tapioka. AGRITECH 34(3) :308-315.

Hartono, S. D. 2010. Optimasi Pembuatan Tepung Millet (Setaria sp.) Termodifikasi dan Aplikasinya Sebagai Bahan Dasar Roti Tawar (Tinjauan dari Kadar Protein Terlarut, Kadar Gizi, dan Asam Amino). Skripsi. Universitas Kristen Satya Wacana.

\section{Saran}

Perlu dilakukan penelitian lebih lanjut terkait aplikasi tepung proso millet dalam pembuatan produk bakery seperti brownies dan sejenisnya.

\section{DAFTAR PUSTAKA}

Ikbal, A. R. 2015. Perkecambahan Biji Benatan (Albizia Splendends). https://www.academia.edu/11471459/perk ecambahan_biji_benatan_Albizia_splende nds_diakses pada tanggal 26 Februari 2019.

Iswari, K. 2014. Pengaruh Lama Fermentasi Terhadap Mutu Tepung Cassava Termodifikasi. Skripsi. Universitas Andalas.

Julianti, E., M. Nurminah, dan G. A. Syahputri. 2017. Pengaruh Metode dan Lama Fermentasi Terhadap Karakteristik Kimia dan Fungsional Tepung Ubi Jalar Oranye. Prosiding Seminar Nasional FKPT-TPI 2017: 97-107.

Kindiki, M.M., A. Onyago dan F. Kyalo. 2015. Effect of Processing on Nutritional and Sensory Quality of Pearl Millet Flour. Food Science and Quality Management 42: $13-19$.

Lombu, W.K. 2018. Perbedaan Karakteristik Kimia dan Daya Cerna Pati Tepung Jagung dan Tepung Kecambah Jagung (Zea Mays L.). Jurnal ITEPA 7(1): 43-51.

Megat, R.M.R. 2012. Effect of Germination on Total Phenolic, Tannin and Phytic Acid Contents In Soy Bean and Peanut. International Food Research Journal 19(2): 673-677.

National Nutrient Database, 2012. Full Report (All Nutrients): 20031, Millet, raw. https://ndb.nal.usda.gov/ndb/foods/show/2 0031 diakses pada tanggal 16 Juni 2018.

Onyago, C.A., S.O. Ochanda dan M.A. Mwasaru. 2013. Effect of Malting and Fermentation 
on Anti-Nutrient Reduction and Protein Digestibility of Red Sorghum, White Sorghum and Pearl Millet. Journal of Food Research 2: 41-49.

Paiki, S.N.P. 2013. Pengaruh Fermentasi Spontan terhadap Karakteristik Fisik dan Kimia Tepung Sorgum (Sorghum bicolor L. Moench) Serta Aplikasinya dalam Pembuatan Cookies. Skripsi. Institut Pertanian Bogor.

Prabowo, B. 2010. Kajian Sifat Fisikokimia Tepung Millet Kuning dan Tepung Millet Merah. Skripsi. Universitas Sebelas Maret.

Rahma, I.N., R. H. Pratama, Alfiyanti, D. R. Alwi, W. I. S. T. Astuti, dan D. H. Wardhani. 2017. Swelling Power and Solubility of Modified Breadfruit Flour using Lactobacillus plantarum. IOP Conf. Series: Journal of Physics: Conf. Series 909 (2) 101-108.

Saputro, M. A, A. Kurniawan, D. S. Retnowati. 2012. Modifikasi Pati Talas dengan Asetilasi Menggunakan Asam Asetat. Jurnal Teknologi Kimia dan Industri 1:258-263.

Schons P. F., E. F.Ries, V. Battestin dan G.A. Macedo (2012). Effect of Enzymatic Treatment on Tannins and Phytate in Millet (Panicum miliaceum) and Its Nutritional Study in Daramola S. T. 211 rats. International Journal of Food Science \& Technology, 46:1253-1258.
Setiarto, R. H. B dan N. Widhyastuti. 2016. Penurunan Kandungan Tanin dan Asam Fitat pada Tepung Sorgum Melalui Fermentasi Rhizoporus oligosporus, Lactobacillus plantarum, dan Saccharomyces cerevisiae. Berita Biologi 15(2): 149-157.

Sulistyaningrum, Rahmawati dan M. Aqil. 2017. Karakteristik Tepung Jewawut (Foxtail Millet) Varietas Lokal Majene dengan Perlakuan Perendaman. Jurnal Penelitian Pascapanen Pertanian 14: 11-21.

Widyaningsih dan A. Mutholib. 1999. Pakan burung. Penerbit Penebar Swadaya. Jakarta.

Wisaniyasa, N.W., IK. Suter., Y. Marsono., dan IN. K. Putra. 2015. Germination Effect on Functional Properties and Antitrypsin Activities of Pigeon Pea (Cajanus Cajan (L.) Millsp.) Sprout Flour. Food Science and Quality Management. 4(3) : 79-84.

Wisaniyasa, N. W. dan I. K. Suter. 2015. Kajian Sifat Fungsional dan Kimia Tepung Kecambah Kacang Merah (Phaseolus vulgaris L.) dan Aplikasinya Menjadi Flakes. Laporan Hibah Unggulan Program Studi. Universitas Udayana.

Yulia, P. 2009. Proses dan Hasil Fermentasi Bahan Pangan. https://www.academia.edu/24673035/pros es_dan_hasil_fermentasi_bahan_pangan. Diakses pada tanggal 26 februari 2019. 